\title{
Distribution of genes encoding adhesins and biofilm formation capacity among Uropathogenic Escherichia coli isolates in relation to the antimicrobial resistance
}

\author{
Ashraf A Kadry, Nour M Al-Kashef, Amira M El-Ganiny
}

Microbiology and Immunology Department, Faculty of Pharmacy, Zagazig University, Zagazig, Egypt.

\begin{abstract}
:
Background: Escherichia coli is the most predominant pathogen involved in UTIs. Mainly, fimbrial surface appendages are implicated in adherence to urothelium besides non-fimbrial proteins.

Objectives: to determine prevalence of genes encoding fimbrial and non-fimbrial proteins among Uropathogenic Escherichia coli (UPEC). Furthermore, distribution of these genes and biofilm formation capacity were investigated in relation to antimicrobial resistance.

Methods: Antimicrobial susceptibility of 112 UPEC isolates was performed using disc diffusion method. ESBL production was confirmed by double disc synergy test. Genes encoding fimbrial and non-fimbrial proteins were detected using PCR and biofilm formation was investigated using microtitre plate assay.

Results: UPEC isolates exhibited high resistance against doxycyclines (88.39\%), $\beta$-lactams (7.14-86.6\%), sulphamethoxazole-trimethoprim (53.75\%) and fluoro-quinolones (50\%). Fifty percent of tested isolates were ESBL producers. PapGII gene was statistically more prevalent among pyelonephritis isolates. SfaS, focG and picU genes were statistically associated with fluoro-quinolone (FQs) sensitive isolates and $\mathrm{Dr} / \mathrm{afaBC}$ gene was statistically associated with ESBL production. Moreover, nonMDR isolates produced sturdier biofilm.

Conclusion: PapGII adhesin variant seems to have a critical role in colonization of upper urinary tract. There is a possible link between antimicrobial resistance and virulence being capable of affecting the distribution of some genes besides its negative impact on biofilm formation.
\end{abstract}

Keywords: Urinary tract infection, Escherichia coli, UPEC, adhesin genes, ESBL, biofilm.

DOI: https://dx.doi.org/10.4314/ahs.v20i1.29

Cite as: Kadry AA, Al-Kashef NM, El-Ganiny AM. Distribution of genes encoding adhesins and biofilm formation capacity among Uropathogenic Escherichia coli isolates in relation to the antimicrobial resistance. Afri Health Sci. 2020;20(1):23847. https://dx.doi.org/10.4314/abs. v20i1.29

\section{Introduction}

Urinary tract infections (UTIs) are one of the most common bacterial infections caused by a wide spectrum of microorganisms, uropathogenic Escherichia coli (UPEC) is the main causative agent of UTIs including community acquired and nosocomial infection ${ }^{1}$. UTIs can be limited to the bladder (cystitis) with mild localized symptoms or extend to the kidney (pyelonephritis) with more serious symptoms which can be developed into life threating septicemia ${ }^{2}$.

\section{Corresponding author:}

Amira M El-Ganiny,

Microbiology and Immunology Department,

Faculty of Pharmacy, Zagazig University,

Zagazig, Egypt.

Mobile: 002-01145051974

Email: amiraganiny@yahoo.com
To establish UTI, the invading UPEC must overcome the repulsive forces present between its surface and the urothelium cells, which is mediated mainly by the mean of chaperon-usher pathway (CUP) fimbrial surface appendages $^{3}$. Fimbrial appendages are a hetero-polymer protein which ends with adhesin protein subunit recognizing and binding to specific receptor allowing the attachment of invading UPEC to urothelium ${ }^{4}$. Type -1 fimbriae is the prototype of this family playing a critical role in the colonization of the bladder through recognition of mannosylated uroplakins receptors within superficial umbrella cell layer of bladder urothelium ${ }^{5}$. UPEC possesses other fimbrial appendages including P-fimbriae, S-fimbriae and F1C fimbriae which recognize different receptors along urinary tract ${ }^{4,6}$. Dr-adhesin family is another member of CUP appendages which is essential for establishment of chronic and recurrent infections ${ }^{7}$.

Moreover, several non fimbrial surface proteins are involved in the colonization of urinary tract such as iron-

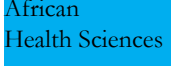

238
(C) 2020 Kadry AA et al. Licensee African Health Sciences. This is an Open Access article distributed under the terms of the Creative commons Attribution License (https://creativecommons.org/licenses/BY/4.0), which permits unrestricted use, distribution, and reproduction in any medium, provided the original work is properly cited.

African Health Sciences Vol 20 Issue 1, March, 2020 
regulated gene A homologue adhesin (Iha) and omp'T protein which are integrated outer membrane proteins ${ }^{8}$, 9. Autotransport (AT) proteins are another class of non-fimbrial proteins which can be either surface localized or secreted into the surrounding environment. Ag43 is a surface localized AT protein involved in long term colonization and formation of biofilm on abiotic surface as well as intracellular bacterial communities ${ }^{10,11}$. PicU is a secreted AT protein facilating the adherence of the invading UPEC by breaking down mucin layer lining the apical surface of the urothelium ${ }^{12}$.

Antimicrobial resistance is mainly due target genes mutation $^{13}$, or acquisition of resistance genes via mobile genetic elements such as plasmid and integrons which could provide co-resistance to different antimicrobial agents ${ }^{14}$. Moreover, biofilm formation provides an additional protective approach by which the encased bacterial cells can avoid the destructive effect of antimicrobial agents as well as drastic environmental conditions ${ }^{15}$. The fact that virulence genes as well as antimicrobial resistance genes could be transferred together by the mean of plasmid or other transferable genetic element besides the capability of the acquired antimicrobial resistance such as fluoro-quinolones (FQs) resistance to affect gene expression among resistant isolates ${ }^{16}$ indicates a possible relationship between the acquired antimicrobial resistance and the virulence. In this study, we determined first the distribution of genes encoding fimbrial and non-fimbrial proteins among cystitis and pyelonephritis UPEC isolates. Then we evaluated if the distribution of these genes as well as the biofilm formation capacity could be affected by the antimicrobial resistance of UPEC isolates.

\section{Materials and methods Bacterial isolates}

A total of 382 clean-catch midstream urine specimens were collected from adult patients (20 - 49 years old) admitted to the outpatient urology clinics of Zagazig university hospitals suffering from symptoms of urinary tract infection in the period from June 2016 to August 2017. Quantitative urine culture was performed using a colony count of $105 \mathrm{CFU} \mathrm{/} \mathrm{mL}$ as a cut off value for positive urine culture ${ }^{17}$.

Out of 180 urine specimens showed significant bacteruria, 112 UPEC isolates were recovered including 65 isolates obtained from patients clinically diagnosed with cystitis and the remaining 47 isolates were obtained from patients with pyelonephritis. All isolates were identified by standard microbiological tests ${ }^{18}$ and stored in Muller Hinton media as $20 \%$ glycerol stocks at $-80^{\circ} \mathrm{C}$.

\section{Antimicrobial susceptibility testing}

The antimicrobial susceptibility was performed using standard disc diffusion method ${ }^{19}$. Tested antimicrobials were belongs to $\beta$-lactams, FQs, aminoglycosides, tetracycline, folate pathway inhibitors and nitrofurans class-

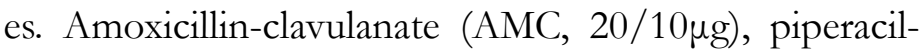
lin-tazobactam (TZP, 100/10 $\mu \mathrm{g}$ ), ceftriaxone (CRO, 30 $\mu \mathrm{g})$, cefpodoxime (CPD, $10 \mu \mathrm{g}$ ), cefuroxime (CXM, 30 $\mu \mathrm{g}$ ), aztreonam (ATM, $30 \mu \mathrm{g}$ ), imipenem (IMP, $10 \mu \mathrm{g}$ ), meropenem (MEM, $10 \mu \mathrm{g})$, gentamicin (CN, $10 \mu \mathrm{g}$ ),

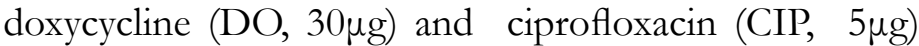
were purchased from Oxoid (Hampshire, UK ). The other antimicrobial discs including levofloxacin (LEV, 5 $\mu \mathrm{g}$ ), ofloxacin (OFX, $5 \mu \mathrm{g}$ ), trimethoprim-sulfamethoxazole (SXT, 1.25/23.75 $\mu \mathrm{g})$ and nitrofurantoin (F, $300 \mu \mathrm{g})$ were obtained from Bioanalysis (Ankra, Turkey). Isolates which were resistant to at least three antimicrobial classes were considered as MDR isolates.

\section{Phenotypic detection of extended spectrum $\beta$-lact- amases (ESBL) production}

Isolates with reduce susceptibility against extended spectrum $\beta$ lactams were considered as potential ESBL according to CLSI guidelines ${ }^{19}$. ESBL production in these isolates was confirmed by double disc synergy test (DDST20). This test depends on the detection of synergy between amoxicillin-clavulanate (AMC, 20/10 $\mu \mathrm{g}$ ) disc which placed at a distance $20 \mathrm{~mm}$ from ceftazidime (CTZ, $30 \mu \mathrm{g}$ ), ceftriaxone (CRO, $30 \mu \mathrm{g}$ ) and cefotaxime (CTX, $30 \mu \mathrm{g}$ ) discs representing third generation cephalosporins along with cefepime (FEB, $30 \mu \mathrm{g})$ disc as a fourth generation cephalosporin. Any distortion or enhancement of the inhibition zone of the tested antibiotics toward amoxicillin-clavulanate disc was considered as a positive result for ESBL production ${ }^{20}$.

\section{Adhesin gene detection using PCR}

Bacterial DNA extraction was performed using optimized heat shock method. Briefly, colonies from overnight culture were suspended in $200 \mu \mathrm{L}$ of sterile water and incubated at $100^{\circ} \mathrm{C}$ for $10 \mathrm{~min}$ and followed by centrifugation where supernatant used as template $\mathrm{DNA}^{21}$.

Primers used in gene amplification were obtained from LGC Biosearch Technologies (Petaluma, CA, USA) and 
were listed in Table 1. Amplification reaction was performed using Biometra $\mathrm{T}$ thermocycler (Analytik Jena, Germany). Each reaction contained $10 \mu \mathrm{L}$ of My'Taq'TM master mix $(2 \mathrm{x}), 1.5 \mu \mathrm{L}$ forward primer, $1.5 \mu \mathrm{L}$ reverse primer, $2 \mu \mathrm{L}$ DNA template and nuclease free water were added to $20 \mu \mathrm{L}$, a negative control reaction without DNA was included for each gene amplification. Amplification products along with Quick-Load 100 bp DNA ladder (New England Biolabs, UK) were electrophorised on 1\% agarose gel containing ethidium bromide $(0.5 \mu \mathrm{g} / \mathrm{mL})$ and visualized using Cole-Parmer UV-transilluminator (Vernon Hills, USA).

\section{In vitro biofilm formation assay}

Biofilm forming capacity was performed according to the method of StepanoviC and coworkers ${ }^{25}$. Briefly, bacterial suspension, from overnight cultures, with a turbidity equivalent to $0.5 \mathrm{McF}$ arland standard was diluted to 1:100 with Tryptone Soya Broth then $100 \mu \mathrm{L}$ aliquots were dispensed into the wells of 96 wells - microtiter plate where the assay was performed as triplicate including blank wells as a negative control. Microtiter plate incubated for 24 $\mathrm{hr}$ at $37^{\circ} \mathrm{C}$, non-adherent cells were removed by washing then adherent cells were fixed by adding $150 \mu \mathrm{L}$ of methanol for $20 \mathrm{~min}$. Formed biofilm was stained with 150 $\mu \mathrm{L} 2 \%$ crystal violet solution for 15 minutes, excess dye removed by washing and adherent dye was solubilized by adding $150 \mu \mathrm{L}$ of $33 \%$ glacial acetic acid for $30 \mathrm{~min}$ Optical density (OD) values were measured at $570 \mathrm{~nm}$ using BioTek synergy HT microtiter plates reader (Ver- mont, USA) and averaged. The cut -off optical density (ODc) value for each plate was calculated according to following equation:

ODc $=$ average OD of negative control $+(3 * \mathrm{SD}$ of negative control).

Biofilm forming capacity was interpreted as: non producer when $\mathrm{OD} \leq \mathrm{ODc}$, weak biofilm producer when ODc $<\mathrm{OD} \leq 2$ ODc, moderate biofilm producer when 2 ODc $<$ OD $\leq 4$ ODc and strong biofilm producer when 4 ODc $<$ OD.

\section{Statistical analysis}

Comparison of proportions was performed using chisquare test using MedCalc program (version 17.11.5). Results with $\mathrm{p} \leq 0.05$ or $\mathrm{p} \leq 0.001$ were marked with single or double asterisks, respectively and considered statistically significant.

\section{Results}

\section{Antimicrobial susceptibility testing}

UPEC isolates exhibited varied susceptibility rates towards different antimicrobials (Figure 1). The highest resistance was observed against doxycycline, amoxacilin-clavulanic acid, cefuroxime and cefpodoxime $(88.39 \%$, $86.8 \%, 71.4 \%$ and $66 \%$, respectively). Intermediate resistance was observed against sulphamethoxazole-trimethoprim (SXT), ceftriaxone, FQs and aztreonam (53.75\%, $51 \%, 50 \%$ and $40.17 \%$, respectively). 


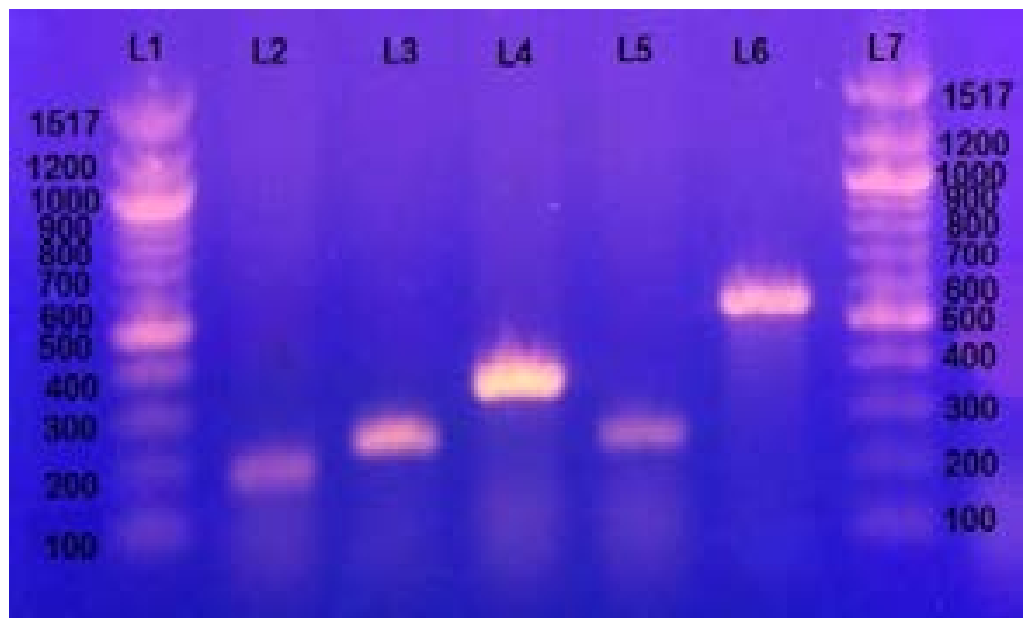

Figure 1. Gel electrophoresis of genes encoding fimbrial adhesins : $\mathbf{L} \mathbf{1}$ and $\mathbf{L} \mathbf{7}$ represent $100 \mathrm{bp}$ DNA ladder, L2 represents $p a p G_{\| /}$allele band approximately at $190 \mathrm{bp}, \mathbf{L} \mathbf{3}$ represents pap $G_{I I I}$ allele band approximately at $258 \mathrm{bp}, \mathbf{L} 4$ represents foc $G$ gene approximately at $360 \mathrm{bp}$, $\mathbf{L}$ represents sfaS gene approximately at $\mathbf{2 4 0} \mathrm{bp}$ and $\mathbf{L} 6$ represents Dr/afaBC gene band approximately at $559 \mathrm{bp}$.

While lower resistance was observed against nitrofurantoin, gentamicin and piperacillin-tazobactam (18.75\%, $17.85 \%$ and $15.18 \%$, respectively). The lowest resistance was against imipenem and meropenem where $7.41 \%$ of tested isolates were resistant for each. Multidrug resistance was observed in $65.2 \%$ of the tested isolates.

\section{Extended spectrum $\beta$ lactamase production}

The initial antimicrobial susceptibility testing revealed that 70 UPEC isolates exhibited a reduced susceptibility towards $\beta$ - lactams. Fifty six isolates were confirmed to be ESBL producers by double disc synergy test representing $50 \%$ of the total UPEC isolates.

\section{Prevalence of adhesin genes among UPEC isolates}

Detection of genes encoding fimbrial and non-fimbrial proteins was done by PCR and all genes gave a single band at the expected size (Table 1) but with different prevalence.

Table. 1: Primers used for amplification of adhesin genes with the corresponding annealing temperature and amplicon size.

\begin{tabular}{|c|c|c|c|c|}
\hline Gene & Primer sequence (5` to $\left.3^{\prime}\right)$ & $\begin{array}{l}\text { Annealing } \\
\text { temperature }\end{array}$ & $\begin{array}{l}\text { Amplicon size } \\
\text { (bp) }\end{array}$ & Reference \\
\hline $\operatorname{Pap}_{I I}$ & $\begin{array}{l}\text { GGGATGAGCGGGCCTTTGAT, } \\
\text { CGGGCCCCCAAGTAACTCG }\end{array}$ & $62^{\circ} \mathrm{C}$ & 190 & Tseng et al. ${ }^{21}$ \\
\hline$P a p G_{I I I}$ & $\begin{array}{l}\text { GGCCTGCAATGGATTTACCTGG, } \\
\text { CCACCAAATGACCATGCCAGAC }\end{array}$ & $65^{\circ} \mathrm{C}$ & 258 & Tseng et al..$^{21}$ \\
\hline$s f a S$ & $\begin{array}{l}\text { GTGGATACGACGATTACTGTG, } \\
\text { CCGCCAGCTTCCCTGTATTC }\end{array}$ & $63^{\circ} \mathrm{C}$ & 240 & $\begin{array}{l}\text { Johnson and } \\
\text { Stell. } .^{22}\end{array}$ \\
\hline focG & $\begin{array}{l}\text { CAGCACAGGCAGTGGATACGA, } \\
\text { GAATGTCGCCTGCCCATTGCT }\end{array}$ & $63^{\circ} \mathrm{C}$ & 360 & $\begin{array}{l}\text { Johnson and } \\
\text { Stell. } .^{22}\end{array}$ \\
\hline Dr/afaBC & $\begin{array}{l}\text { GGCAGAGGGCCGGCAACAGGC, } \\
\text { CCCGTAACGCGCCAGCATCTC }\end{array}$ & $69^{\circ} \mathrm{C}$ & 559 & $\begin{array}{l}\text { Johnson and } \\
\text { Stell. } .^{22}\end{array}$ \\
\hline Ag43 & $\begin{array}{l}\text { CTGGAAACCGGTCTGCCCTT } \\
\text { CCTGAACGCCCAGGGTGATA }\end{array}$ & $63^{\circ} \mathrm{C}$ & 433 & $\begin{array}{l}\text { Restieri et } \\
\text { al. }^{23}\end{array}$ \\
\hline $\operatorname{pic} U$ & $\begin{array}{l}\text { ACTGGATCTTAAGGCTCAGGAT } \\
\text { GACTTAATGTCACTGTTCAGCG }\end{array}$ & $60^{\circ} \mathrm{C}$ & 572 & $\begin{array}{l}\text { Restieri et } \\
\text { al. }^{23}\end{array}$ \\
\hline Iha & $\begin{array}{l}\text { CTGGCGGAGGCTCTGAGATCA } \\
\text { TCCTTAAGCTCCCGCGGCTGA }\end{array}$ & $65^{\circ} \mathrm{C}$ & 827 & $\begin{array}{c}\text { Johnson et } \\
\text { al. }^{24}\end{array}$ \\
\hline ompT & $\begin{array}{l}\text { ATCTAGCCGAAGAAGGAGGC } \\
\text { CCCGGGTCATAGTGTTCATC }\end{array}$ & $60^{\circ} \mathrm{C}$ & 559 & $\begin{array}{c}\text { Johnson et } \\
a^{2 .^{24}}\end{array}$ \\
\hline
\end{tabular}


Among the fimbrial adhesin genes (Figure $1 \&$ Table 2), papG gene alleles (papGII and pagGIII) were the most prevalent (49.1\%) followed by focG gene $(14.3 \%), \mathrm{dr} /$ afaBC gene $(9.8 \%)$ and sfaS gene $(8.9 \%)$. For the genes encoding non fimbrial proteins (Figure 2 \& Table 2), ag43 gene was the most prevalent $(89.3 \%)$ followed by ompT gene $(51.8 \%)$ and iha gene $(31.25 \%)$, while picU gene was detected only in $9.8 \%$ of strains.

Among papG gene alleles, papGII allele was more prevalent than papGIII allele (43.8\% vs. 5.3\%). papGII allele was statistically more prevalent in pyelonephritis isolates than cystitis isolates while the remaining genes showed no significant difference between the two clinical groups (Table 2).

Table 2: prevalence of adhesin genes among cystitis and pyelonephritis isolates

\begin{tabular}{|cccc|}
\hline Gene & $\begin{array}{c}\text { Total } \\
\text { UPEC isolates } \\
\mathbf{n = 1 1 2 ( \% )}\end{array}$ & $\begin{array}{c}\text { Cystitis } \\
\text { isolates } \\
\mathbf{n = 6 5}(\%)\end{array}$ & $\begin{array}{c}\text { Pyelonephritis } \\
\text { isolates } \\
\mathbf{n = 4 7}(\mathbf{6})\end{array}$ \\
PapG & $55(49.1)$ & $27(41.5)$ & $28(59.5)$ \\
PapGII & $49(43.8)$ & $23(35.4)$ & $26(55.3)^{*}$ \\
PapGIII & $6(5.3)$ & $4(6.2)$ & $2(4.25)$ \\
FocG & $16(14.3)$ & $10(15.4)$ & $6(12.7)$ \\
SfaS & $10(8.9)$ & $6(9.2)$ & $4(8.5)$ \\
Dr/afa & $11(9.8)$ & $6(9.2)$ & $5(10.6)$ \\
Ag43 & $100(89.3)$ & $58(89.2)$ & $42(89.36)$ \\
Iha & $35(31.25)$ & $18(27.6)$ & $17(36.17)$ \\
PicU & $11(9.8)$ & $8(12.3)$ & $3(6.38)$ \\
OmpT & $58(51.8)$ & $33(50.7)$ & $25(53.19)$ \\
\hline
\end{tabular}

$\left.{ }^{*}\right)$ p-value $\leq 0.05,(* *)$ p-value $\leq 0.001$

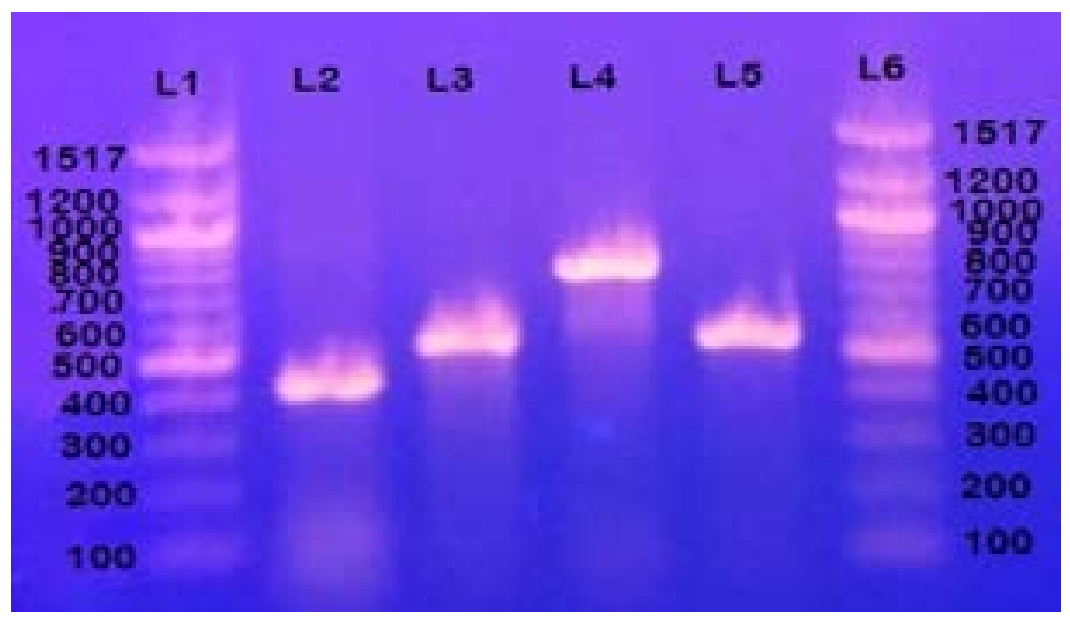

Figure 2. Gel electrophoresis of genes encoding afimbrial proteins: L1 and L6 represent 100bp DNA ladder, L2 represents gene encoding $A g 43$ autotransport protein band approximately at 433 bp. $\mathbf{L 3}$ represents gene encoding secreted autotransprt protein pic $U$ band approximately at 572 bp, L4 gene encoding outer membrane protein Iha band approximately at 827 bp and L5 represents gene encoding outer membrane protein ompt band approximately at $559 \mathrm{bp}$. 
Distribution of the adhesin genes in relation to antimicrobial resistance

Prevalence of genes encoding fimbrial and non fimbria proteins was assessed in relation to increased resistance rate towards SXT and FQs as well as ESBL production (Table 3).

Table 3: distribution of genes encoding fimbrial and non fimbrial proteins in relation to FQs, SXT resistance and ESBL production.

\begin{tabular}{|c|c|c|c|c|c|c|}
\hline Gene & $\begin{array}{c}\text { FQ-sensitive } \\
n=56(\%)\end{array}$ & $\begin{array}{c}\text { FQ- } \\
\text { Resistant } \\
\mathrm{n}=56(\%)\end{array}$ & $\begin{array}{c}\text { SXT- } \\
\text { Sensitive } \\
\text { n=52 (\%) }\end{array}$ & $\begin{array}{c}\text { SXT- } \\
\text { Resistant } \\
\text { n=60 (\%) }\end{array}$ & $\begin{array}{c}\text { ESBL }^{(\mathrm{a})} \text { Producer } \\
\text { n=56 (\%) }\end{array}$ & $\begin{array}{c}\text { Non-ESBL } \\
\text { Producer } \\
\text { n=56 (\%) }\end{array}$ \\
\hline$P a p G_{I I}$ & $21(37.53)$ & $28(50)$ & $20(38.46)$ & $29(48.3)$ & $24(42.8)$ & $25(44.6)$ \\
\hline$P a p G_{I I I}$ & $4(7.14)$ & $2(3.5)$ & $4(7.8)$ & $2(3.3)$ & $2(3.7)$ & $4(7.1)$ \\
\hline Foc $G$ & $14(25)^{* *}$ & $2(3.5)$ & $9(17.3)$ & 7 (11.6) & $6(10.7)$ & $10(17.8)$ \\
\hline SfaS & $9(16.1)^{* *}$ & $1(1.8)$ & $8(15.4)^{*}$ & $2(3.3)$ & $4(7.2)$ & $6(10.7)$ \\
\hline$D r / a f a B C$ & $4(7.14)$ & $7(12.5)$ & $3(5.7)$ & $8(13.3)$ & $9(16.1)^{*}$ & $2(3.5)$ \\
\hline Ag43 & $48(85.7)$ & $52(92.9)$ & 44 (84.6) & $56(93.3)$ & $50(89.2)$ & $50(89.2)$ \\
\hline Iha & $16(28.6)$ & $19(33.9)$ & $15(28.8)$ & $20(33.3)$ & $18(32.1)$ & $17(30.35)$ \\
\hline$P i c U$ & $10(17.9)^{* *}$ & $1(1.8)$ & $8(15.4)$ & $3(5)$ & $5(8.9)$ & $6(10.7)$ \\
\hline OmpT & $34(60.7)$ & $24(42.8)$ & $28(53.8)$ & $30(50)$ & $33(59)$ & $25(44.6)$ \\
\hline
\end{tabular}

(a): Only isolates which were confirmed to be ESBL producer by DDST.

(*) p-value $\leq 0.05,(* *)$ p-value $\leq 0.001$

In relation to $\mathrm{FQ}$ s resistance; $\mathrm{sfaS}$, focG and picU genes were statistically associated with sensitive strains. ompT gene was more prevalent in sensitive isolates than resistant isolates but it was non-significant $(\mathrm{p}=0.059)$.

sfaS gene was statistically associated with isolates sensitive to SXT than resistant ones. picU gene was more prevalent in sensitive isolates but it was non-significant $(p=0.066)$.

In relation to ESBL production, $\mathrm{dr} / \mathrm{afaBC}$ gene was statistically associated with ESBL producing strains while the remaining traits showed a similar prevalence among ESBL producing and non-producing strains.

Biofilm formation capacity in relation to antimicrobial resistance:

The biofilm formation capacity of 73 MDR isolates and 39 non MDR isolates was evaluated to determine the impact of multiple drug resistance on biofilm formation capacity (Table 4).

Table 4: Biofilm formation capacity among MDR and non-MDR isolates.

\begin{tabular}{|cccc|}
\hline $\begin{array}{c}\text { Biofilm } \\
\text { forming } \\
\text { capacity }\end{array}$ & $\begin{array}{r}\text { Total UPEC isolates } \\
\mathbf{n = 1 1 2}(\mathbf{\%})\end{array}$ & $\begin{array}{c}\text { MDR isolates } \\
\mathbf{n = 7 3}(\mathbf{\%})\end{array}$ & $\begin{array}{c}\text { Non- MDR } \\
\text { isolates } \\
\mathbf{n = 3 9}(\mathbf{\%})\end{array}$ \\
Negative & $23(20.53)$ & $17(23.28)$ & $6(15.38)$ \\
Weak & $39(34.8)$ & $31(42.46)^{*}$ & $8(20.51)$ \\
Moderate & $27(24.1)$ & $14(19.18)$ & $13(33.33)$ \\
Strong & $23(20.53)$ & $11(15)$ & $12(30.78)^{*}$ \\
\hline (*) $p$-value $\leq 0.05,(* *) p$-value $\leq 0.001$ & &
\end{tabular}


Non-MDR isolates were statistically more capable of producing strong biofilm than MDR isolates and the percentage of non-MDR isolates that could form moderate biofilm was higher than MDR isolates. While MDR isolates statistically tended to form weak biofilm thanon-MDR isolates and the percentage of MDR isolates that couldn't form biofilms was higher than non MDR isolates.

\section{Disscusion}

UPEC is the main causative agent involved in UTIs. Adherence to the uroepithelium is a critical step to establish an infection. This step is achieved mainly by fimbrial surface appendages beside other non-fimbrial adhesins. Fimbrial appendages recognize and adhere to certain receptors favoring the tropism of invading pathogen towards a given region within urinary tract ${ }^{6}$.

UTIs are usually treated empirically especially uncomplicated infections. The selective overuse in addition to the misuse of certain antimicrobial classes, especially those with high propensity for collateral damage, is the main cause of high resistance rates and increased percentages of MDR isolates ${ }^{26}$. MDR isolates represents a serious health problem in $\mathrm{Egypt}^{27}$.

In this study, the increased resistance rate among UPEC isolates especially against $\beta$-lactams, SXT and FQs limits their role in the treatment of such infections. Fifty percent of tested isolates were ESBL producers coming in agreement with other studies in Egypt ${ }^{28,29}$. Moreover, the increased resistance against SXT and FQs was in consistent with previous studies ${ }^{30,31}$.

The genotypic detection of genes encoding fimbrial and non-fimbrial adhesins revealed that papGII allele was observed to be statistically more prevalent in pyelonephritis isolates than cystitis isolates. This statistical predominance of pyelonephritis UPEC isolates was in agreement with other studies ${ }^{32,33}$. This predominance along with the abundance of papGII isoreceptor in kidney tissue indicates the role of papGII adhesin variant in ascending infection ${ }^{4}$.

The impact of the antimicrobial resistance on the distribution of tested genetic traits was evaluated in the term of resistance towards FQs and SXT, representing the highest resistance rates among non- $\beta$ lactams, in addition to ESBL enzyme production being the main resistance mechanism for $\beta$ lactams.
The observed negative impact of FQs resistance acquisition on the prevalence of tested adhesin genes was obvious where three virulence traits including sfaS, focG and picU were statistically more prevalent in sensitive isolates. This statistical prevalence was compatible with other studies $^{34-36}$. This negative impact could be as a result of acquisition of FQs resistance by strains naturally lacking these virulence factors followed by clonal spreading. This hypothesis was denied by Vila and coworkers ${ }^{37}$ stated that there was no genetic relationship between these tested isolates using pulsed-field gel electrophoresis. Another possible explanation for this negative impact is related to the mutational efect of fluroquinolone. Exposure to even sub-inhibitory concentrations of FQs not only leads to the acquisition of resistance but also induces SOS response which could lead to partial or total loss of pathogenicity islands within which these virulence genes could be located ${ }^{38,39}$.

The impact of SXT resistance acquisition on gene prevalence was quite similar to FQs where sfaS trait was statistically more prevalent in sensitive isolates.

However, $\mathrm{dr} / \mathrm{afaBC}$ gene was statistically more prevalent among ESBL-producing isolates being consistent with Johnson and co-workers demonstrating that $\mathrm{dr} / \mathrm{afaBC}$ gene was statistically associated with resistance to extended spectrum cephalosporins and cephamycins among UPEC isolates ${ }^{40}$. This could be related to the co-existence of certain virulence genes along with resistance genes on mobile genetic element like plasmid providing a dual survival advantages to recipient pathogen ${ }^{41}$.

The negative impact of the acquired antibiotic resistance on the biofilm forming capacity among UPEC was previously reported among Acinetobacter baumannii isolates ${ }^{42}$. Similarly, Poursina and coworkers ${ }^{43}$ reported that $69.2 \%$ of strong biofilm-producing UPEC isolates were non-MDR isolates while negative and weak biofilm producing isolates were MDR isolates.

Several surface appendages including fimbriae and curli in addition to other non-fimbrial proteins are involved in the biofilm architecture as a supporting scaffold. The acquisition of antimicrobial resistance could affect the expression of these organelles which negatively affect the biofilm formation capacity ${ }^{44}$. Vila and coworkers ${ }^{37}$ reported that the expression of type-1 fimbriae among FQ resistant UPEC isolates was statistically lower than sensitive isolates. Similarly, the acquisition of gene encoding ESBL enzymes was previously reported to possess a negative 
impact on the biofilm formation capacity in E. coli and Pseudomonas aeruginosa ${ }^{45}$. All of these results confirm that acquisition of antimicrobial resistance could have a negative impact on the biofilm formation capacity among UPEC isolates.

\section{Conclusion}

papGII adhesin variant is an important urovirulence factor seeming to have a critical role in ascending UTIs. The acquired antimicrobial resistance could affect the distribution of certain virulence genes. Moreover, there is an inverse relationship between the biofilm forming capacity and the multiple drug resistance among UPEC isolates indicating the role of biofilm formation as an alternative protective approach especially for susceptible isolates as well as a possible link between antimicrobial resistance and virulence.

\section{Conflict of interest}

The authors declare that they have no conflict of interest

\section{References}

1. Da Silva GJ and Mendonça N. Association between antimicrobial resistance and virulence in Escherichia coli. Virulence. 2012; 3(1):18-28.

2. Mahon CR. Textbook of diagnostic microbiology, Fifth edition: Elsevier Health sciences 2015; 1: 884-901

3. Flores-Mireles AL, Walker JN, Caparon M, Hultgren SJ. Urinary tract infections: epidemiology, mechanisms of infection and treatment options. Nature Reviews Microbiology. 2015; 13(5): 269-284

4. Proft T, Baker EN. Pili in Gram-negative and Gram-positive bacteria, structure, assembly and their role in disease. Cellular and Molecular Life Sciences. 2008; 66(4): 161-169.

5. Spaulding CN, Hultgren SJ. Adhesive pili in UTI pathogenesis and drug development. Pathogens. 2016; 5(1), 30.

6. Antão EM, Wieler LH, Ewers C. Adhesive threads of extraintestinal pathogenic Escherichia coli. Gut Pathogens. 2009; 1(1): 22

7. Nowicki B, Selvarangan R, Nowicki S. Family of Escherichia coli Dr adhesins: decay-accelerating factor receptor recognition and invasiveness. The Journal of Infectious Diseases. 2001; 183(1): S24-S27.

8. Johnson JR, Jelacic S, Schoening LM, Clabots C, Shaikh N, Mobley HLT et al. The IrgA homologue ad- hesin Iha Is an Escherichia coli virulence factor in murine urinary tract Infection. Infection and Immunity. 2005; 73(2): 965-971.

9. Hritonenko V, Stathopoulos C. Omptin proteins: an expanding family of outer membrane proteases in gram-negative Enterobacteriaceae. Molecular Membrane Biology. 2007; 24(5-6): 395-406.

10. Klemm P, Hjerrild L, Gjermansen M, Schembri Mark A. Structure-function analysis of the self-recognizing Antigen 43 autotransporter protein from Escherichia coli. Molecular Microbiology. 2003; 51(1): 283-296.

11. Zalewska-Piatek B, Zalewska-Piatek R, Olszewski M, Kur J. Identification of antigen Ag43 in uropathogenic Escherichia coli Dr+ strains and defining its role in the pathogenesis of urinary tract infections. Microbiology. 2015; 161(5): 1034-1049.

12. Heimer SR, Rasko DA, Lockatell CV, Johnson DE, Mobley HLT. Autotransporter genes pic and tsh are associated with Escherichia coli strains that cause acute pyelonephritis and are expressed during urinary tract infection. Infection and Immunity. 2004; 72(1): 593-597.

13. Shariff VAAR, Shenoy MS, Yadav T, M R. The antibiotic susceptibility patterns of uropathogenic Escherichia coli, with special reference to the fluoroquinolones. Journal of Clinical and Diagnostic Research. 2013; 7(6): 10271030.

14. Kadry AA, Serry FM, El-Ganiny AM, El-Baz AM. Integron occurrence is linked to reduced biocide susceptibility in multidrug resistant Pseudomonas aeruginosa. British Journal of Biomedical Sciences. 2017; 74(2): 78-84.

15. Stewart PS. Mechanisms of antibiotic resistance in bacterial biofilms. International Journal of Medical Microbiology. 2002; 292(2): 107-113.

16. Yamane T, Enokida H, Hayami H, Kawahara M, Nakagawa M. Genome-wide transcriptome analysis of fluoroquinolone resistance in clinical isolates of Escherichia coli. International Journal of Urology. 2011; 19(4): 360-368. 17. Wilson ML, Gaido L. Laboratory diagnosis of Urinary tract Infections in adult patients. Clinical Infectious Diseases. 2004; 38(8): 1150-1158.

18. Koneman E, Winn WJ. Koneman's Color Atlas and Textbook of Diagnostic Microbiology, $6^{\text {th }}$ ed. Lippincott Williams \& Wilkins, London, 2006.

19. Clinical and Laboratory Standards Institute. Performance Standards for Antimicrobial Susceptibility Testing; Twenty $2^{\text {nd }}$ informational Supplement. CLSI document M100S22. Wayne, PA, USA, 2012

20. Garrec H, Drieux-Rouzet L, Golmard J-L, Jarlier 
V, Robert J. Comparison of nine phenotypic methods for detection of Extended-Spectrum $\beta$-Lactamase production by Enterobacteriaceae. Journal of Clinical Microbiology. 2011; 49(3): 1048-1057.

21. Tseng CC, Huang JJ, Ko WC, Yan JJ, Wu JJ. Decreased predominance of papG class II allele in Escherichia coli strains isolated from adult with acute pyelonephritis and urinary tract abnormalities. The Journal of Urology. 2001; 166(5): 1643-1646.

22. Johnson JR, Stell AL. Extended virulence genotypes of Escherichia coli strains from patients with urosepsis in relation to phylogeny and host compromise. The Journal of Infectious Diseases. 2000; 181(1): 261-272.

23. Restieri C, Garriss G, Locas MC, Dozois CM. Autotransporter-encoding sequences are phylogenetically distributed among Escherichia coli clinical isolates and reference strains. Applied and Environmental Microbiology. 2007; 73(5): 1553-1562.

24. Johnson JR, Russo TA, Tarr PI, Carlino U, Bilge SS, Vary JC et al. Molecular epidemiological and phylogenetic associations of two novel putative virulence genes, iha and iroN E. coli, among Escherichia coli isolates from Patients with urosepsis. Infection and Immunity. 2000; 68(5): 3040-3047.

25. StepanoviĆ S, VukoviĆ D, Hola V, Bonaventura Giovanni DI, DjukiĆ S, ĆIrkoviĆ I et al. Quantification of biofilm in microtiter plates: overview of testing conditions and practical recommendations for assessment of biofilm production by Staphylococci. Journal of pathology, microbiology and immunology. 2007; 115(8): 891-899.

26. Gupta K, Hooton TM, Naber KG, Wullt B, Colgan $\mathrm{R}$, Miller LG et al. International clinical practice guidelines for the treatment of acute uncomplicated cystitis and pyelonephritis in women: A 2010 update by the infectious diseases society of America and the European society for microbiology and infectious diseases. Clinical Infectious Diseases. 2011; 52 (5), 103-120.

27. Abbas HA, El-Ganiny AM, Kamel HA. Phenotypic and genotypic detection of antibiotic resistance of Pseudomonas aeruginosa isolated from urinary tract infections. African Health Sciences, 2018; 18(1): 11-21.

28. Morsi SS, Tash MR. Virulance determinants among Extended-spectrum B-lactamases producers of uropathogenic Escherichia coli isolates in Zagazig university hospitals, Egypt. Egyptian Journal of Medical Microbiology. 2016; 25(2): 101-108.

29. Elsayed TI, Ismail HA, Elgamal SA, Gad AH.
The occurrence of multidrug resistant E. coli which produce ESBL and cause urinary tract infections. Journal of Applied Microbiology and Biochemistry. 2017; 1: 2-8

30. Das R, Perrelli E, Towle V, Van Ness PH, Juthani-Mehta M. Antimicrobial susceptibility of bacteria isolated from urine samples obtained from nursing home residents. Infection Control and Hospital Epidemiology. 2009; 30(11): 1116-1119.

31. Neamati F, Firoozeh F, Saffari M, Zibaei M. Virulence genes and antimicrobial resistance pattern in uropathogenic Escherichia coli isolated from hospitalized patients in Kashan, Iran. Jundishapur Journal of Microbiology. 2015; 8(2): 257-262

32. Kudinha T, Johnson JR, Andrew SD, Kong F, Anderson P, Gilbert GL. Distribution of phylogenetic groups, sequence type ST131, and virulence-associated traits among Escherichia colii solates from men with pyelonephritis or cystitis and healthy controls. Clinical Microbiology and Infection. 2013; 19(4): 173-180.

33. Qin X, Hu F, Wu S, Ye X, Zhu D, Zhang Y, et al. Comparison of adhesin genes and antimicrobial susceptibilities between uropathogenic and intestinal commensal Escherichia coli Strains. PLoS One. 2013; 8(4): 61169

34. Johnson JR, O’Bryan TT, Low DA, Ling G, Delavari $\mathrm{P}$, Fasching Cand, et al. Evidence of commonality between canine and human extraintestinal pathogenic Escherichia coli strains that express papG Allele III. Infection and Immunity. 2000; 68(6): 3327-3336.

35. Moreno E, Prats G, Sabaté M, Pérez T, Johnson JR, Andreu A. Quinolone, fluoroquinolone and trimetho$\mathrm{prim} / \mathrm{sulfamethoxazole} \mathrm{resistance} \mathrm{in} \mathrm{relation} \mathrm{to} \mathrm{virulence}$ determinants and phylogenetic background among uropathogenic Escherichia coli. Journal of Antimicrobial Chemotherapy. 2006; 57(2): 204-211.

36. Ferjani S, Saidani M, Ennigrou S, Hsairi M, Slim AF, Boutiba Ben Boubaker I. Multidrug resistance and high virulence genotype in uropathogenic Escherichia coli due to diffusion of ST131 clonal group producing CTX-M-15: an emerging problem in a Tunisian hospital. Folia Microbiologica. 2014; 59(3): 257-262.

37. Vila J, Simon K, Ruiz J, Horcajada J P, Velasco M, Barranco M, et al. Are quinolone-resistant uropathogenic Escherichia coli less virulent?. The Journal of Infectious Diseases. 2002; 186(7), 1039-1042.

38. Soto SM, Jimenez de Anta MT, Vila J. Quinolones induce partial or total loss of pathogenicity islands in uropathogenic Escherichia coli by SOS-dependent or -inde- 
pendent pathways, Respectively. Antimicrobial Agents and Chemotherapy. 2006; 50(2): 649-653.

39. Qin T-T, Kang H-Q, Ma P, Li P-P, Huang L-Y, $\mathrm{Gu}$ B. SOS response and its regulation on the fluoroquinolone resistance. Annals of Translational Medicine. 2015; 3(22): 358

40. Johnson JR, Kuskowski MA, Owens K, Gajewski, A, Winokur PL. Phylogenetic origin and virulence genotype in relation to resistance to fluoroquinolones and/ or Extended-spectrum cephalosporins and cephamycins among Escherichia coli isolates from animals and humans. The Journal of Infectious Diseases. 2003; 188(5): 759-768 41. Johnson JR, Kuskowski MA, O'Bryan TT, Colodner R, Raz R. Virulence genotype and phylogenetic origin in relation to antibiotic resistance profile among Eschericbia coli urine sample isolates from Israeli women with acute uncomplicated cystitis. Antimicrobial Agents and Chemotherapy. 2005; 49(1): 26-31.
42. Qi L, Li H, Zhang C, Liang B, Li J, Wang L, et al. Relationship between antibiotic resistance, biofilm formation, and biofilm-specific resistance in Acinetobacter baumannii. Frontiers in Microbiology. 2016; 7: 483.

43. Poursina F, Sepehrpour S and Mobasherizadeh S. Biofilm formation in non multidrug-resistant Eschericbia coli isolated from patients with urinary tract infection in Isfahan, Iran. Advanced Biomedical Research. 2018; 7, 40.

44. Soto SM, Smithson A, Martinez JA, Horcajada JP, Mensa J, Vila J. Biofilm formation in uropathogenic Escherichia coli strains: Relationship with prostatitis, urovirulence factors and antimicrobial resistance. The Journal of Urology. 2007; 177(1): 365-368.

45. Gallant CV, Daniels C, Leung JM, Ghosh AS, Young KD, Kotra LP, et al. Common $\beta$-lactamases inhibit bacterial biofilm formation. Molecular microbiology. 2005; 58(4): 1012-1024 